\title{
O ATO MORAL SEgundo ToMÁs DE AQUiNo
}

\author{
Paulo Martines ${ }^{1}$
}

Resumo: Ao considerar as açốes que são propriamente humanas, as quais pertencem ao homem enquanto homem, Tomás de Aquino destaca aquelas açôes que procedem da vontade deliberada e que visam a um determinado fim, uma orientação que será caracterizada como algo inscrito no próprio ser da criatura e acompanhada de certo conhecimento. Este artigo almeja estudar a constituiçáo do ato moral para Tomás, fazendo ressaltar náo apenas a centralidade da vontade na constituição desse ato, mas também certos assuntos pertinentes à reflexão tomasiana do ato moral, como a distinção voluntário/involuntário, a coexistência de inteligência e vontade na determinação do ato humano e a qualificação da ação que é imperada pela vontade, pois é nela que se manifestará de modo mais claro o agir ético para Tomás, demarcado este pelo signo da prudência. A referência textual de Tomás, aqui utilizada, diz respeito à segunda parte da Suma de teologia.

Palavras-chave: Vontade. Liberdade. Ação. Prudência.

Moralia mensura est ratio.

(Tomás de Aquino, Summa contra gentiles, III, c. 3)

Toda ação principia mesmo é por uma palavra pensada. Palavra pegante, dada ou guardada, que vai rompendo rumo.

(Guimarães Rosa, Grande Sertão: Veredas)

O tema da ação moral (ação propriamente humana) repercute em diversas obras de Tomás de Aquino, seja em seus comentários (Sententia libri ethicorum), seja nas questôes disputadas (Quaestiones disputatae De virtutibus e Quaestiones disputatae De malo), mas é especialmente na segunda parte da Suma de teologia que encontramos a formulação de uma scientia moralis, de

\footnotetext{
${ }^{1}$ Professor associado da Universidade Estadual de Maringá (UEM), Maringá, PR - Brasil. (D) http:// orcid.org/0000-0001-6396-696X E-mail: prmartines@uem.br

http://dx.doi.org/10.1590/0101-3173.2019.v42esp.14.p249
} 
um tractatus moralium, como anunciava a primeira parte da Suma de teologia ${ }^{2}$. No desenho da Suma de teologia, a segunda parte instaura a reflexão sobre a liberdade da criatura, feita à imagem e semelhança de Deus, e cuja primeira coisa a refletir é sobre o fim último da vida humana. Uma tal proposição considera a liberdade criada, finita e marcada pelo pecado, peregrina, numa linguagem agostiniana, a qual se pôe em marcha para a sua transformação e construção, a fim de ordenar suas intençôes e açôes a um tal fim. $\mathrm{O}$ estudo da açáo e de sua qualificação moral será feito de um ponto de vista filosófico e teológico, uma conjugação que, na história do pensamento medieval, tem na expressão “inteligência da fé”, atribuída a Anselmo de Cantuária, o seu ponto de partida.

A reflexão de ordem filosófica sobre a ética será apresentada numa obra que recebe o nome de Suma de teologia. Tomás era um mestre em teologia, doutor da verdade cristá e eminente professor da Universidade de Paris, no séc. XIII. Suas obras enfrentam a grande tradição precedente (greco-árabe) e o número de autores citados (de Aristóteles, Dionísio e Avicena) é muito significativo. Comentou uma dezena de obras de Aristóteles e de filósofos neoplatônicos, muitas vezes preocupado em resolver determinado tema de seu pensamento teológico. Certa vez, empregou a expressão "filósofo moralista" por oposição à "teólogo", ao mencionar o tratamento diferenciado que cada um deles oferece ao problema do pecado. Ao filósofo, o pecado é contrário à razão natural; ao teólogo, é uma ofensa a Deus. O que existe é que ambos consideram o ato moralmente mau, sob ponto de vista diferentes $\left(S T, \mathrm{I}^{\mathrm{a}} \mathrm{II}^{\mathrm{ae}}\right.$, q. 71, a. 6, ad $\left.5^{\mathrm{um}}\right)$.

Filosofia e teologia são diversas, mas há uma complementaridade entre ambas: o que as une é o estreito desejo natural do homem pelo saber. A fé pressupóe o conhecimento natural, há uma autonomia e legitimidade da filosofia; enquanto teólogo, Tomás leva a sério as exigências da filosofia. Em suas palavras, a filosofia é "legítima e louvável” (ST, I ${ }^{\mathrm{a}} \mathrm{II}^{\mathrm{ae}}$, q. 167, a. 1, ad $\left.3^{\mathrm{um}}\right)$.

${ }^{2}$ TOMÁS DE AQUINO, Suma de teologia $\mathrm{I}^{\mathrm{a}}$, q. 83, a. 2, ad $3^{\mathrm{um}}$. Para o texto da Summa theologiae, utilizo, salvo mençâo em contrário, a edição brasileira intitulada Suma teológica, São Paulo: Ediçōes Loyola, 2003. Essa referência da Suma diz respeito à primeira parte, questão 83, artigo segundo e resposta à terceira objeçáo. Doravante emprego a abreviatura $S T$ para me referir à Suma de teologia, e SCG para me referir à Suma contra os gentios. 
Para a reflexão da ação moral aqui encetada, há de se ressaltar o papel central que recobre a ideia latina de ordo ou ordinatio para o vocabulário moral, de Tomás de Aquino. Assim como há uma ordem das coisas ou do mundo (ordo rerum/ordo universi), há de se encontrar uma ordem racional das paixóes e das açóes do homem, e reconhecer que a inteligência é um princípio ativo e ordenador do real, de tal sorte que a ordem da inteligência é chamada a se impor em suas funçôes teóricas e práticas. O domínio da filosofia prática é aquele referente à ordenação da ação humana.

O modo sistemático e estruturante pelo qual Tomás enfrenta seus temas exige, logo de início, a divisão do tema proposto. A segunda parte da Suma de teologia é a mais extensa da obra, contendo duas partes, da qual a primeira parte (Prima secundae) contém 114 artigos assim divididos: a beatitude (q. 1-5), a estrutura (q. 6-17) e a moralidade (q. 18-21) dos atos humanos; as paixóes em geral (q. 22-25) e, em particular (q. 26-48); os habitus em geral (q. 49-54) e os habitus bons em geral (q. 55-70); o pecado (q. 71-89); a lei (q. 90-108); a graça (q. 109-114). A segunda parte (Secunda secundae) contém 189 artigos, dos quais se estudam as virtudes e os vícios particulares (q. 1-170) e, depois, os diferentes estados (status) humanos (q. 171-189). No âmbito da ciência moral, as questóes 6-17 discutem os atos da vontade (elícitos e imperados) e a qualificação moral de tais atos (q. 18-21). As questóes iniciais (q. 1-5) refletem sobre a felicidade última à qual aspira toda natureza racional, discussão prévia de toda açáo moral. Tomo como ponto de partida uma passagem extensa de Tomás, a qual servirá de guia para a minha análise:

Das açóes realizadas pelo homem, são propriamente humanas as que pertencem ao homem enquanto homem. $\mathrm{O}$ homem se diferencia das criaturas irracionais porque tem o domínio de seus atos. Por isso, somente são ditas propriamente humanas aquelas açōes sobre as quais o homem tem domínio. Ora, o homem tem domínio de suas açóes pela razão e pela vontade. Donde será chamada de livre-arbítrio a "faculdade da vontade e da razáo". Assim sendo, são propriamente ditas humanas as açóes que procede da vontade deliberada. Se outras açóes, são próprias do homem, poderão ser chamadas de açôes do homem, mas não são propriamente açôes humanas, pois não são do homem enquanto homem. ( $S T$, $\mathrm{I}^{\mathrm{a}} \mathrm{II}^{\mathrm{ae}}$, q. 1 , a. 1 , grifo nosso). 
Este artigo abre a discussão propriamente moral da Suma de teologia, investigando a conveniência de a ação humana visar a um determinado fim, isto é, a tendência implícita da ação humana para o fim último. Essa orientação será pontuada como algo inscrito no próprio ser da criatura e acompanhado de um certo conhecimento.

O termo ação (actio), ou o seu verbo correspondente agir (agere), designa para um sujeito o fato de agir ou de sua operação, sendo estendido assim aos animais irracionais; mas é, antes de tudo, à dimensão dos atos humanos que Tomás se refere, ao usar o termo ação. De uma forma bastante ampla, essa terminologia sistematizou aquilo que, em moral, pode ser compreendido como atos humanos e atos do homem. Todavia, para o propósito deste estudo, interessa destacar dessa passagem a centralidade do termo vontade e investigar certos problemas pertinentes à reflexão do ato moral de Tomás, como a distinção voluntário/involuntário, a coexistência da inteligência e vontade na determinação do ato humano e a qualificação daquela ação que é imperada pela vontade, pois é nela que se manifestará de modo mais claro o agir ético para Tomás, o qual se dará sob o signo da prudência. Assim, tratarei 1) da vontade; 2) da caracterização geral do livre-arbítrio; e 3) da eficácia do ato prudencial.

\section{A vontade}

Cabe ao homem, como algo que lhe é próprio, dirigir-se para o seu fim, o que é feito por açóes voluntárias. $\mathrm{O}$ ato humano procede, por sua vez, de uma inclinação interna ao que se lhe é acrescentado um julgamento sobre o fim a ser perseguido e sobre as vias de alcançá-lo. Tais açóes recobrem duas exigências, para Tomás de Aquino: ter em si mesmo o princípio de seu movimento e ter o conhecimento do fim: há certas coisas em que "há um princípio intrínseco não só para mover-se, mas que sejam movidas para o fim" (ST, $\mathrm{I}^{\mathrm{a}} \mathrm{II}^{\text {ae }}$, q. 6, a. 1, grifo nosso). É apenas de um modo indireto ou derivado que se pode dizer que os animais (e as crianças) agem de maneira voluntária, pois o que especifica o voluntário na criatura racional é a sua capacidade de refletir e deliberar sobre certos atos que dizem respeito ao fim visado. A expressáo quod est actuum dominus é a forma de Tomás descrever agentes que possuem livre escolha, isto é, agentes capazes de atos voluntários ou humanos ${ }^{3}$.

${ }^{3}$ A propósito do princípio do movimento voluntário, cabe ressaltar uma noção aristotélica importante de que Tomás se valerá, para tratar do livre-arbítrio: "É livre aquele que é causa de si mesmo." (ST, Ia, q. 83, a. 1, obj. 3). A explicação e o desenvolvimento completo dessa tese são oferecidos por Tomás, no Comentário à Metafísica de Aristóteles. Convém frisar que essa afirmação do estagirita se refere ao ser 
$\mathrm{O}$ voluntário pertence àquilo que procede da vontade, que é livre em sua ação e náo pode ser coagido de modo algum. Pertence à vontade, então, a capacidade ou o domínio de agir ou não agir: ela é senhora de seu ato (domina est sui actus) e possui o querer ou não querer $\left(S T, \mathrm{I}^{\mathrm{a}} \mathrm{II}^{\mathrm{ae}}\right.$, q. 8 , a. 3 , sed contra). Em outras palavras, há um dinamismo voluntário do homem em direção a um fim determinado, decidido este pela vontade, com o apoio de atos intermediários.

A vontade é um apetite racional. $\mathrm{O}$ termo apetite, em seu sentido amplo, é identificado como uma potência especial da alma, comum aos seres animados e inanimados; e um princípio intrínseco de atividade, que conduz ao fim que lhe é exterior. $\mathrm{O}$ alcance filosófico dessas afirmaçóes é enorme para a reflexão aqui apresentada, pois Tomás (1) considera o apetite segundo as determinaçôes da Física ("todas as coisas naturais são ordenadas aos efeitos que lhes convém”); (2) se distancia de Agostinho, por afirmar que a vontade (que é um apetite racional) não é um simples querer, mas uma potência racional que tem um fim determinado; e (3) reconhece que na hierarquia dos entes criados há, na parte superior, seres que se movem a si mesmos, na parte inferior, os seres que são movidos e, na parte intermediária, seres cuja composição de espírito e corpo faz com que tenham uma parte motora e outra que é movida.

A vontade, entendida como uma tendência para algo, é colocada em presença de um objeto que lhe é oferecido pela inteligência e que determinará a especificação de seu ato, cabendo à vontade a determinação na dimensão de seu exercício, aceitando ou recusando o que lhe é proposto. O objeto da ação moral é portador de um sentido moral: "O bem é apresentado à vontade pela razão como objeto, e, enquanto está sob a ordem da razão, pertence ao gênero moral e causa bondade moral no ato da vontade." (ST, I ${ }^{\mathrm{a}}$, q. 19 , a. 1, ad $\left.3^{\mathrm{um}}\right)$. Temos aqui a conhecida distinçáo entre a liberdade de especificação e a liberdade de exercício. Toda vontade é uma "natureza" da qual certas inclinaçôes lhe brotam de forma espontânea, de sua condição "natural" ( $S T$, $\mathrm{I}^{\mathrm{a}}$, q. 18, a. 3), que a conduz, ao modo de uma inclinação, ao bem em geral, ao fim último. O bem (bonum) é o objeto natural do querer, ele exprime o apetecível do ser a uma tendência apetitiva natural ou elícita; o bonum é quod omnia appetunt. Bem e fim se identificam, e o primeiro princípio da

livre (ser por causa de si mesmo), em oposição ao escravo. De fato, para Aristóteles, o que está em jogo não é a concepção de liberdade, mas a de escravidão. Tomás entende a causa sui como "ser causa de seu próprio movimento", uma compreensão para além da noção social-política de Aristóteles. Também na Suma contra os Gentios, Tomás usa a expressão causa sui para indicar causalidade agente, isto é, para indicar que o agente é causa de seu próprio movimento ou operação (SCG, III, c. 112). 
moral é encontrado na fórmula "o bem deve ser praticado e procurado, o mal deve ser evitado". Ao remeter a uma realidade que o transcende, Tomás afirma que o homem é capaz do sumo bem, porque seu intelecto pode apreender o bem perfeito e universal, e sua vontade pode desejá-lo $\left(S T, \mathrm{I}^{\mathrm{a}} \mathrm{II}^{\mathrm{ae}}\right.$, q. 5, a. $1)^{4}$. Pensar dessa forma náo seria abrir espaço para o determinismo de nossas açóes? A resposta é negativa, pois, diante da dúvida acerca da escolha humana, se livre ou necessária, Tomás é enfático ao declarar que a tese determinista não somente é herética, mas que ela destrói a moral inteira (De malo, q. 6). O teólogo Tomás de Aquino sabe que as Escrituras afirmam o papel da ação eficaz de Deus sobre a vontade do homem ${ }^{5}$, mas reconhece, com precisão, não se tratar de uma violência, porque Deus pode mover a vontade, fazê-la querer, amar e escolher. Por fim, a vontade é um princípio ativo que náo é determinada a uma alternativa, porém, permanece aberta (indifferenter se habens) diante de múltiplas alternativas.

Para aprofundar a questão da vontade, vale ressaltar o papel central que exerce o ato das potências (intelectual e sensitiva) e seus respectivos objetos. $\mathrm{O}$ ato de uma potência frente ao objeto pressupóe a uniáo prévia com esse objeto que o determina. Para o conhecimento intelectual, a especificação de seu ato se dá segundo uma semelhança (similitudo) que torna presente o objeto à inteligência. No caso da potência sensitiva, não há similitude do objeto na potência apetitiva, contudo, certa adaptação de ordem afetiva (coaptatio), resultante do movimento primeiro do amor: "Percebendo um objeto que me convém, ponho-me a amá-lo, e nesse amor até a minha vontade se conforma de algum modo a esse objeto que se torna efetivamente presente para mim." (GARDEIL, 2013, p. 165). A ética de Tomás é assim fundada no amor do bem, anterior ao dever e à lei, o qual se tornará princípio de motivação e legitimação primordiais.

A descrição dos apetites a partir de seus objetos reconhecerá uma distinção fundamental na potência sensitiva: a presença do apetite concupiscível e do apetite irascível $\left(S T, \mathrm{I}^{a}\right.$, q. 81 , a. 2) A potência intelectual tem somente a capacidade racional. A concupiscível e a irascível são definidas na medida em que os seus objetos nos inclinam para algo: pela primeira, a alma é inclinada a perseguir o que é agradável e rejeitar o que é prejudicial; já a segunda impele o animal a resistir àquilo que se lhe opóe. Tomás se vale do seguinte argumento:

\footnotetext{
${ }^{4}$ Ver, a esse respeito, as análises de Jean-Malo Beaufort (2007, p. 44).

5 "Como ribeiro de água, assim o coração do rei na mão de Javé, este, segundo o seu querer, o inclina." (BÍBLIA DE JERUSALÉM, 1985, Pr 21,1).
} 
É preciso considerar o seguinte: as coisas corruptíveis da natureza devem ter não só uma inclinação para conseguir o que lhes convém e fugir do que lhes é nocivo, mas ainda uma inclinaçáo para resistir às causas da corrupção e aos agentes contrários que póem obstáculo à aquisiçáo do que convém, e produzem o que é danoso. (ST, $\mathrm{I}^{\mathrm{a}}$, q. 82, a. 5).

Uma dificuldade se apresenta: porque a distinção entre as inclinaçôes de prazer e resistência a algo fornece a divisão do apetite sensitivo, enquanto a vontade permanece unificada pela razão? A resposta a essa questão aparece mais adiante, quando Tomás investiga se a vontade pode ser distinguida em concupiscível e irascível. A resposta é negativa, porque a vontade unifica tudo aquilo que ela deseja "sob a noção geral de bem", e o apetite sensitivo é incapaz de fazer isso, porque é incapaz de alcançar os universais:

Assim, as partes do apetite sensitivo se diversificam pelas diversas noçóes de bens particulares. Pois, a parte concupiscível se refere à própria noção de bem enquanto é agradável aos sentidos e conveniente à natureza. A parte irascível, porém, se refere à noção de bem na medida em que repele e combate o que é prejudicial. Mas a vontade se refere ao bem sob a noção geral de bem. (ST, I’a q. 82, a. 5, tradução nossa).

A diferença de gênero, assim estabelecida entre as potências apetitivas, mostra a diferença fundamental de como cada apetite opera: julgamento baseado em uma noção geral de bem produz desejos diferentes daqueles proeminentes de estímulos sensitivos.

Se o apetite sensitivo pode ser concebido como resposta a certo estímulo, o apetite racional avalia e julga se determinada alternativa (a ser escolhida) satisfaz a concepção daquilo que é entendido como um bem. A vontade é um apetite racional e as açôes voluntárias devem ser escolhidas pela vontade. Tomás relaciona o desejo da vontade com o agir segundo razóes, o que parece tornar plausível o fato de que açóes voluntárias são escolhidas pela vontade. Mais: a escolha voluntária implica razão, de modo que é impossível uma escolha sem conhecimento, no entanto, náo deixa de ser um apetite, um dinamismo interno de sua natureza, alterado pela razão. Em outros termos, a vontade é uma capacidade que permite ao seu possuidor inclinar-se a objetos intelectualmente apreendidos como bons e afastar-se de objetos reconhecidamente maus. As açóes de tal vontade são precedidas de certa cogniçãao intelectual, não no sentido de que compreender produza voliçóes, mas de que a razão possa fornecer a causalidade 
final/formal que especifique os movimentos os quais o próprio apetite faz, em resposta a fins ou formas conhecidas.

É na parte final da discussão sobre os atos estruturados da vontade $-S T$, $\mathrm{I}^{\mathrm{a}} \mathrm{II}^{\mathrm{ae}}$, q. 17 - que aparecerá o conceito o qual servirá de síntese para exprimir a conjugação harmoniosa de vontade e intelecto: aquele de imperium ${ }^{6}$. Tratase aqui dos atos imperados da vontade, isto é, comandados pela vontade. Enquanto o ato elícito é ele mesmo um ato específico (seja na compreensão da escolha, seja no julgamento e uso), o ato imperado designa a conjunçáo de um ato sobre o outro. Trata-se de uma ordem, uma comunicação de ordem que é expedida, quer da razão sobre a vontade, quer da vontade sobre as faculdades inferiores. No ato da escolha, a ordem do intellectus recai sobre a electio da vontade ou sobre o iudicium da razão. $\mathrm{Na}$ ordem, está o aspecto concreto da execução de uma decisão. Imperar é mover alguma coisa, "é um ato da razão que pressupóe o ato da vontade" $\left(S T, \mathrm{I}^{\mathrm{a}} \mathrm{II}^{\mathrm{ae}}, \mathrm{q} \text {. } 17 \text {, a. } 1\right)^{7}$. Há uma interconexão entre esses atos, pois, quando a razáo reflete sobre o querer e a vontade quer refletir, a vontade é posterior à razão: "E porque a virtude do ato anterior permanece no ato posterior, se dá às vezes que há algum ato da vontade no qual permanece virtualmente algo do ato da razão." ( $S T$, $\mathrm{I}^{\mathrm{a}} \mathrm{II}^{\mathrm{ae}}$, q. 16 , a. 1). Imperar ou comandar é um ato da razão, porque o que impera ordena o que é imperado para agir, "intimando ou advertindo" (ST, $\mathrm{I}^{\mathrm{a}} \mathrm{II}^{\mathrm{ae}}$, q. 16, a. 1).

Dar ordens é próprio do intelecto e não se encontra nos animais. A execução de uma decisão para atingir determinado fim é consecutiva a uma ordem. $\mathrm{Na}$ execução de uma ordem, os atos são realizados em função dessa ordem e formam entre si uma unidade. Os atos das potências inferiores da alma são determinados pela ordem das faculdades superiores e constituem, dessa maneira, $o$ ato humano, assim como um instrumento e a causa principal realizam conjuntamente uma determinada ação. Há unidade da vida interior no pensamento de Tomás.

A ordem é um ato do intelecto para que algo seja feito, e tal ordem é dirigida primeiramente à vontade. $\mathrm{O}$ homem, dotado de razão e sensibilidade, comanda os atos da vontade $\left(S T, \mathrm{I}^{\mathrm{a}} \mathrm{II}^{\mathrm{ae}}\right.$, q. $\left.17, \mathrm{ad}^{\mathrm{um}}\right)$. Mas esses atos

\footnotetext{
${ }^{6} \mathrm{O}$ sentido primário desse termo latino está associado ao poder que alguém exerce sobre outro, tendo, na linguagem política e militar, o seu emprego mais comum. Seria mais apropriado traduzir o verbo imperare, em português, por ordenar ou comandar, porque, no contexto ético tomásico, significa a conjunção de um ato da razão, o qual estabelece uma ordem, com um ato da vontade, que dá impulso e faz agir.

7 Noutra passagem da Suma de teologia, ao abordar a conjugação das faculdades espirituais, Tomás menciona uma inclusão mútua: "Intellectus et voluntas se includent." (ST, Iª q. 16, a. 4, ad $\left.1^{\mathrm{um}}\right)$.
} 
comandados pela razão não são os primeiros atos da vontade, porque esta é ela mesma ordenada ao bem. O que temos até aqui é a definição de império como um ato da razão contendo um impulso voluntário. $\mathrm{O}$ império se liga à virtude da prudência.

Pode-se, assim, sintetizar a concepção de vontade para Tomás de Aquino de três formas: 1) a vontade se autodetermina para a realização de seu ato, isto é, ela própria se move; 2 ) a vontade, ao escolher determinado bem, é precedida por um ato do intelecto; 3) a felicidade como causa última de toda ação humana move a vontade de modo necessário.

\section{O LiVRe-ARbítrio}

É sob a compreensão do livre-arbítrio enquanto conjugação de razão e vontade que a dimensão da ação humana é considerada mais detalhadamente por Tomás de Aquino. A construção afirmativa do livre-arbítrio, de acordo com a questáo 83 da primeira parte da Suma de teologia, se dá a partir de uma citação do Antigo Testamento: "Deus criou o homem no começo e o deixou na mão de sua deliberação', isto é, na sua liberdade de arbítrio." ( $S T$, $\mathrm{I}^{\mathrm{a}}$, q. 83, a. 1 , sed contra) ${ }^{8}$. Essa referência ao livre-arbítrio parece apontar para a capacidade (interior) que o homem possui de tomar decisóes, o que corresponderia ao domínio de suas próprias açóes. De uma forma mais direta, Tomás é levado a reconhecer a existência do livre-arbítrio com base na afirmação da vida moral, pois, sem ele, "os conselhos, as exortações, os preceitos, as proibiçóes, as recompensas e os castigos seriam vãos" ( $S T, \mathrm{I}^{\mathrm{a}}$, q. 83, a. 1). A liberdade se apresenta como parte essencial da moralidade. Isso pode ser comprovado pela consideração do ato (livre), em outras palavras, pelo modo de ação que corresponde ao homem, o que se torna mais claro, quando comparado às outras criaturas. Há seres que agem sem julgamento (seres inanimados); há seres que agem com julgamento, porém, não são livres (animais). Deve-se admitir que os animais possuem, cada um segundo sua constituição natural, uma espécie de "conhecimento" que funciona tal como um julgamento; por exemplo, a ovelha que foge ao avistar o lobo. E, por fim, há a criatura humana que age segundo um julgamento, pelo qual procura ou evita aquilo que deve. Esse julgamento (livre) pertence à capacidade cognoscitiva, cabendo à razão (em seu uso prático) o exercício próprio da comparação (collatio) entre as diversas realidades que se apresentam diante

${ }^{8}$ A citação bíblica é de Eclesiástico, 15,14. 
de si. Não se trata de um julgamento da esfera especulativa, mas da decisão prática, que não é outra coisa senão a escolha (iudicium electionis).

A operação da razão se abre para a esfera das realidades contingentes, de sorte que ela se apresenta diante de coisas diversas (se habet ad diversa) e não é determinada a uma só coisa (ad unum). Deve-se notar que, para Tomás, a ação humana é aquela em que o homem (1) tem o domínio de suas açôes, isso pela conjugação, e não composição, de razão e vontade, e que (2) procede de uma vontade deliberada $\left(S T, \mathrm{I}^{\mathrm{a}} \mathrm{II}^{\mathrm{ae}}\right.$, q. 1, a. 1). Ora, tal pensamento permite ao mestre dominicano afirmar, nessa mesma passagem, que o livre-arbítrio é a faculdade da vontade e da razão. Ademais, os atos humanos são reconhecidos como voluntários, por terem o princípio de seu movimento em si mesmos (in agente), em vista de um fim, o que pressupóe que esse fim seja conhecido.

$\mathrm{O}$ ato livre é assim reconhecido mediante a presença do julgamento, que, como tal, pertence à capacidade cognoscitiva do homem, em outras palavras, à sua razão. Deve-se frisar que o livre-arbítrio é, para Tomás, uma potência (= capacidade) da alma, e não um hábito, pois, segundo este, o homem seria inclinado naturalmente para certos objetos. Como será possível entender o poder próprio do livre-arbítrio? Poderíamos reconhecê-lo como a capacidade racional presente no ato de julgar, o qual, ao comparar, escolhe aquilo que é considerado melhor?

O livre-arbítrio é uma potência apetitiva e a eleição (electio) é o seu ato próprio. Tomás relembra a definição de electio como "o desejo das coisas que estão em nosso poder", de acordo com as palavras de Aristóteles, em sua Ética Nicomaqueia (ARISTÓTELES, 1999, III, 5, 1113a9-12). É de um modo duplo que essa escolha será considerada: previamente à escolha, existe a deliberação (consilium), pela qual o homem pondera, compara e julga aquilo que de melhor pode ser estabelecido para determinada ação; e, depois, tem a possibilidade de aceitar ou rejeitar aquilo que é julgado. $\mathrm{O}$ primeiro diz respeito à faculdade cognoscitiva; o segundo, à faculdade apetitiva. Toda escolha recai sobre os meios pelos quais (sempre em poder do agente) se pode alcançar o fim desejado. O livre-arbítrio está penetrado de razão, mas, em seu conceito formal, ele é idêntico à vontade. Essa dupla constituição permite a Tomás relembrar outra passagem da ética de Aristóteles, que faz da escolha "ou um intelecto que deseja, ou um desejo que julga”.

O termo grego proairesis, comumente traduzido por "escolha", tem seu registro filosófico na Ética Nicomaqueia, inicialmente no livro III (caps. 2 e 
3), quando do desenvolvimento da análise sobre as virtudes morais e, depois, no livro VI (cap. 2), ao considerar a ação moral. O prefixo do termo indica a ideia de que algo é feito antecipadamente, como se na escolha houvesse um momento anterior do qual resultasse a escolha propriamente dita. Esse momento anterior é o trabalho do logos prático, explicitado na deliberação (boulesis). Deliberar é um trabalho de investigação, coordenado pela razão, com o fim de indicar qual deve ser a melhor escolha possível. Em termos filosóficos, cabe à deliberaçáo a seguinte pergunta: como devo fazer algo? Assim, a escolha para Aristóteles é precedida pela deliberação e requer a presença da razão e pensamento: "A escolha é um desejo deliberado que depende de nós" (ARISTÓTELES, 1999, III, 5, 1113a10); em outros termos, a escolha é uma ação voluntária fundada racionalmente: deliberada e refletida. Escolha, deliberação e desejo são três termos presentes no coração da ética de Aristóteles e que definem o ato moral. Tomás é tributário desse pensamento, fato que permite vislumbrar a estreita relaçáo entre o pensamento grego e o mundo cristão na formulação de sua filosofia.

O julgamento implicado no reconhecimento do livre-arbítrio é pensado como a conclusão daquilo que é determinado pela razão, cabendo à vontade aceitar ou não tal determinação. Nesse sentido, a escolha recai, em sua determinação última, sobre a potência apetitiva. Deve-se ressaltar que a liberdade, conforme Tomás, apresenta o concurso (inter-relacionado) de razáo e vontade, mas, como a escolha se dirige a um bem particular, ela deve ser entendida como um movimento apetitivo. $\mathrm{O}$ livre-arbítrio pertence à vontade.

A questão 13 da Prima Secundae da Suma, ao considerar a escolha como a constituinte fundamental do ato humano, demarca com precisão o papel desempenhado pela razáo e pela vontade: a razáo precede a vontade e ordena o ato; a vontade tende para um fim que é indicado pela razáo. Valendose da analogia matéria-forma, Tomás afirma que o ato humano livre pertence materialmente à vontade e formalmente à razão. Uma dupla constituição, através da qual, uma vez mais, Tomás faz questáo de relembrar Aristóteles, para quem, na escolha, há a presença de uma inteligência que deseja e de um desejo inteligente. Assim, a escolha - da qual não podemos esquecer a noção de preferência de uma coisa em relação a outra - não pode ser a manifestação de qualquer desejo, mas daquele que possui um certo discernimento. Os animais irracionais não escolhem, porque são determinados "só para uma coisa" (ad unum), o que se explica pelo apetite sensitivo, pelo qual esses seres são determinados segundo a sua ordem natural, muito distinta da vontade 
humana. O homem pode se manter independente em relação às coisas externas, pois fixa para si mesmo sua própria orientação, na medida em que conhece seu fim e os meios para alcançá-lo.

\section{A PRUDÊNCIA}

O último passo da determinação do ato moral, para a compreensão de sua realização e concretude, é oferecido pela prudência, porque com ela se alcança a lucidez, a retidão e a firmeza das decisôes que o homem é levado a tomar, na condução de sua vida. A prudência é algo que diz respeito à razão, em sua função prática, aplicando à ação singular os princípios morais $\left(S T\right.$, II ${ }^{a}$ $\mathrm{II}^{\mathrm{ae}}, \mathrm{q} .47$, a. 1 e 2 ).

Tomás de Aquino, ao longo da questão 47 (segunda seção da segunda parte da Suma de teologia), mobiliza autoridades filosóficas e cristãs para tratar sobre a prudência: Aristóteles, Agostinho e Isidoro de Sevilha servem como ponto de partida para o estabelecimento de que a prudência pertence ao domínio do conhecimento racional, pois implica previsão (em seu aspecto providencial) e confronto de dados. Também, a prudência é uma atividade que se vincula à razão prática e recebe, pelo viés aristotélico, a definição de recta ratio agibilium, cuja tradução literal é "a reta razão do agir", mas podendo ser vertida para o português como o "reto proporcionamento do que é matéria de ação” (NASCIMENTO, 1993, p. 370). Ela é uma aplicação das regras gerais à ação, daí pertencer, também, à ordem do singular: "É próprio da prudência não só a consideração da razão, mas também a aplicação à obra, que é o fim da razão prática." (ST, $\mathrm{II}^{\mathrm{a}} \mathrm{II}^{\mathrm{ae}}$, q. 47 , a. 3).

Ao se abordar o lugar da prudência entre as virtudes, se sabe que ela não possui apenas a capacidade de julgamento, todavia, ela é essencialmente ligada à retidão do apetite; é, pois, uma virtude em seu sentido pleno, já que é distinta das virtudes intelectuais especulativas e dos hábitos de ordem prática, e distinta de outras virtudes morais que aperfeiçoam outras potências da inteligência. Pode-se sustentar que ela "representa não só a articulação entre o universo intelectual dos princípios e da ação, mas sobretudo a articulação entre a tendência para o fim último da vontade e a escolha concreta do que se ordena a este fim" (NASCIMENTO, 1993, p. 372).

A prudência determina apenas o que é ordenado ao fim e não o próprio fim, pois, como no domínio da especulação a ciência versa sobre as conclusóes, 
obtidas a partir dos primeiros princípios especulativos, assim também, no domínio da ação moral, a prudência versa sobre as conclusóes, obtidas em função dos primeiros princípios práticos conhecidos e que equivalem aos fins das virtudes morais. À prudência cabe determinar o meio adequado e razoável do agir humano, em outras palavras, cabe determinar a conveniente ordenação do que se refere ao fim. Tomás toma emprestada de Aristóteles a ideia de silogismo prático, a partir da analogia com o silogismo demonstrativo: "Assim como na razão especulativa há certos conhecimentos naturais [...] também preexistem na razão prática alguma coisa como os princípios naturalmente conhecidos que são os fins das virtudes morais.” (ST, $\mathrm{II}^{\mathrm{a}} \mathrm{II}^{\mathrm{ae}}$, q. 47, a. 6). Ainda que estranhos ao vocabulário aristotélico, Tomás chamará esses princípios práticos de sinderése: "Deve-se dizer que as virtudes morais recebem seu fim da razão natural chamada sindérese." $\left(S T, \mathrm{II}^{\mathrm{a}} \mathrm{II}^{\mathrm{ae}}\right.$, q. 47, a. 6, ad $\left.1^{\text {um }}\right)$. Como defini-la na arquitetura conceitual da moral tomasiana? Sabe-se que ela é um hábito natural, porque se ordena para o bem; nunca erra, pois o erro só pode dar-se na aplicação particular do conhecimento, jamais nos primeiros princípios universais e naturais; e, por fim, é uma retidão imutável, como o resquício da luz divina na natureza humana. Tomás se refere a um intellectus principiorum na esfera da práxis e lhe subordina a prudentia, assim como acontece com a scientia, a qual se subordina ao intellectus principiorum no domínio da teoria (NASCIMENTO, 1993, p. 373).

O fim próprio das virtudes morais consiste na conformidade com a reta razão, e cabe a esta ordenar e determinar como o ser humano encontra o meio razoável, visto que cabe à temperança a tarefa de que o homem náo se afaste da razão por causa da intemperança, como cabe à fortaleza que ele não se afaste do reto julgamento da razáo por causa do medo ou da audácia. Os caminhos pelos quais o homem atinge o meio termo da razáo competem à prudência.

O artigo 8 da questão 47 considera o ato próprio da prudência, núcleo dessa questáo e ponto decisivo para a nossa análise. Eis o texto central de Tomás:

\footnotetext{
9 Esse termo provém de syntéresis e significa "conservação", empregado por S. Gerônimo no comentário ao profeta Ezequiel, para se referir aos primeiros princípios morais. Trata-se da conservação desses princípios, que, à maneira de uma centelha, indica a cada um os desvios que possa incorrer no cumprimento das leis morais. A razão prática tem como tarefa confrontar esses dados primeiros com aquilo que sabe e conhece, a fim de aplicá-los à determinada situação. Daqui surge a noçáo de consciência moral (TORREL, 1996).
} 
A prudência é a reta razão do que deve ser feito, já foi dito. Portanto, é necessário que o ato principal da prudência seja o ato principal da razáo orientado ao que deve ser feito. Nela se distinguem três atos: o primeiro é deliberar, ao qual compete a descoberta, porque deliberar é procurar. $\mathrm{O}$ segundo ato é o julgamento relativo ao que foi descoberto, o que é função da razão especulativa. Mas a razão prática, ordenada à ação efetiva, vai mais longe e é seu terceiro ato, comandar. Este ato consiste em aplicar à ação o resultado obtido na descoberta e no julgamento E porque este ato está mais próximo do fim da razáo prática, se segue que este é o ato principal da razão prática e, consequentemente da prudência. ( $S T, \mathrm{II}^{\mathrm{a}} \mathrm{II}^{\mathrm{ae}}, \mathrm{q} .47$, a. 8 ).

Ora, três atos definem a prudência: a deliberação ou conselho, que consiste em descobrir ou procurar; o julgamento, que consiste em julgar o que foi descoberto; e, por fim, o comandar, que consiste em aplicar o que foi deliberado e julgado no operar; é este o mais próximo da razão prática e, assim, da prudência. Pode-se afirmar que este último ato se identifica com o ato da decisão, definido no âmbito do comando ou império. Na resposta à terceira objeção desse artigo, Tomás relembra os termos da questão 17 que expusemos mais acima, ao declarar que o comandar (praecipere) implica moção acompanhada de ordem e, por isso, trata-se de um ato da razáo.

Apontar a identificaçáo entre império e prudência supóe a posteridade estrutural do império em relação à escolha, o que não significa que a prudência só intervenha na ação humana depois de tudo acabado, pois a sua intervenção se dá através da deliberação e do juízo que encerra tal deliberação.

MARTINES, P. The moral act according to Thomas Aquinas. Trans/Form/Ação, Marília, v. 42, p. 249-264, 2019. Edição Especial.

ABSTRACT: In considering actions that are properly human, which belong to man as man, Thomas Aquinas highlights those actions that proceed from deliberate will and aim at a certain end. This orientation is characterized as something inscribed in the very being of the creature and accompanied by knowledge of a certain kind. This article aims to study the constitution of the moral act for Aquinas. It emphasizes not only the centrality of the will in the constitution of this act, but also certain issues pertinent to Aquinas' reflection on the moral act. For example, the voluntary/involuntary distinction, the coexistence of intelligence and will in the determination of the human act, and the qualification of action dominated by the will. It is in action that the ethical act for Aquinas is most clearly manifested, 
marked by the sign of prudence. The primary text referred to in this article is the second part of the Summa theologiae.

KeYwords: Will. Freedom. Action. Prudence.

\section{REFERÊNCIAS}

ARISTÓTELES. Etica Nichomachea. Tradução: Carlo Natali. Roma: Laterza, 1999.

BEAUFORT, J.-M. La valeur morale de nos actes selon Saint Thomas d'Aquin. Paris: Pierri Téqui, 2007.

BÍBLIA DE JERUSALÉM. São Paulo: Paulus, 1985.

GARDEIL, H.-D. Iniciação à filosofia de São Tomás de Aquino. São Paulo: Paulus, 2013.

NASCIMENTO, C. A. R. A prudência segundo São Tomás de Aquino. Sintese, Belo Horizonte, v. 20, n. 62, p. 365-385, 1993.

PINCKAERS, S. La structure de l'acte humain suivant Saint Thomas. Revue Thomiste, v. 55, p. 393-412, 1955.

TOMÁS DE AQUINO. 'De Malo', il male e la libertà. Tradução: Umberto Galeazzi. Milano: BUR, 2002.

TOMÁS DE AQUINO. Suma teológica. Tradução: Carlos-Josaphat P. de Oliveira et al. São Paulo: Loyola, 2001-2006. 9 v.

TOMÁS DE AQUINO. Suma contra os gentios. Tradução: Maurílio J. de Oliveira Camello. São Paulo: Loyola, 2015. v. 3.

TORREL, J-P. Thomas d'Aquin. In: CANTO-SPERBER, M. (dir.). Dictionnaire d'étique et de philosophie morale. Paris: PUF, 1996.

Recebido: 30/12/2019

Aceito: 30/12/2019 
MARTINES, P. 